\title{
Disadvantaged Employees in the Trap of Defined Contribution Pension Plans
}

Submitted 26/07/21, 1st revision 17/08/21, 2nd revision 24/09/21, accepted 18/10/21

\author{
Ravit Rubinstein-Levi ${ }^{1}$
}

\begin{abstract}
:
Purpose: The Defined Contribution (DC) saving method, which is implemented in most Organization for Economic Cooperation and Development (OECD) countries, is generally detrimental to disadvantaged employees. This paper proposes to improve the situation of disadvantaged employees by increasing government regulatory intervention, through an aggregation model.

Design/Methodology/Approach: The study is conducted based on Israeli data and examines the impact of the aggregation model suggested in it, at the microeconomic level.

Findings: Disadvantaged employees usually fail to accumulate sufficient pension savings and pay the highest management fees. Therefore, after retirement, their substitution ratio is low, and they suffer from poverty. Several population groups, such as immigrants, can be generally considered disadvantaged. The measures taken by governments to mitigate the problem do not succeed in bringing about a significant change.

Practical Implications: The aggregation model presented in this paper offers a way to significantly improve the pension savings of disadvantaged employees. The model enables the implementation of compulsory pension law, thereby creates pension savings among all disadvantaged employees. In addition to that, the model enables to reduce the management fees paid by disadvantaged employees, and thus raise their future pension.

Originality/Value: Given the similarity between Israel and other OECD countries in the context of pension savings, other countries may benefit from the research findings presented in this paper as well.
\end{abstract}

Keywords: Pension, Disadvantaged Employees, Management fees, Retirement, Regulatory intervention.

JEL Classification: J3, D14, J26, E2, E21.

Research type: Research paper.

${ }^{1}$ Ben-Gurion University of the Negev, ravitru@post,bgu.ac.il 


\section{Introduction}

Studies conducted in most western countries point at the self-guided savings method, a.k.a. "Defined Contribution" (DC) $)^{2}$ as a contributor to exacerbation in retirees' income inequality, poverty, and dependence on government support (Been et al., 2017).

DC pensions are flexible and accommodate a diverse range of retirement savings behavior (Banks and Smith, 2006). Most adults do not have the knowledge needed to make the necessary retirement savings decisions due to the high levels of financial sophistication needed (Lusardi and Mitchell 2017; Lusardi and Alessie, 2011). Research suggests improving pension savings by implementing financial literacy across the population (Lusardi and Alessie, 2011). However, this is a difficult task given the complexity of the issue and its dynamic nature (Worthington, 2008).

Governments in OECD countries, use various means to improve the financial state of retirees. Tax incentives are the most significant incentive given by governments, designed to encourage employees to increase their retirement savings and reduce their dependency on support payments (Harrison et al., 2006; Jenkins, 2005). However, most employees are almost unaffected by the incentives due to their confusion regarding the issue (Sewin, 2008). Other measures designed to improve the financial state of retirees in OECD countries are compulsory pensions, ageadjusted default savings tracks, etc. Yet, poverty rates among retirees are currently substantially higher than in the general population, and they are expected to increase (Bleikh, 2016). Poverty projections in the United States predict that $33 \%$ of future American retirees will be either poor or near-poor when they retire, and $55 \%$ of retirees will be forced to rely solely on their Social Security income (Ghilarducci et al., 2015).

Lower-income individuals are usually referred to as disadvantaged. When it comes to disadvantaged employees, who are low earners, there are two main obstacles to pension savings in the DC saving system. First, lower incomes are associated with a lower probability of contributing to pension savings and less significant contributions (Heim and Lurie, 2014). Accordingly, disadvantaged employees fail to accumulate sufficient pension savings. Second, since management fees in pension funds in the DC system tend to be higher for small accounts than for large accounts (Turner, 2000), disadvantaged employees usually pay high management fees.

To address the first obstacle, the need for comprehensive pension coverage to all employees, many governments instituted a mandatory pension law, which exists in different versions. In Israel, the mandatory pension law came into effect in January

\footnotetext{
${ }^{2}$ According to the DC method, the employees are responsible for choosing their pension funds and pension schemes, and the employees will also bear the risk (Oehler and Werner, 2008).
} 
2008. For a variety of reasons, the law is currently not enforced, and as of 2015 , about $40 \%$ of employees in Israel lack pension savings. To address the obstacle of high management fees, many countries limited the management fees that a pension fund can charge from the savers. However, the maximum management fees are often very high. In Israel, the maximum management fees are extremely high, $6 \%$ of the contributions, and $0.5 \%$ of the accrued reserve in the pension fund.

Although governments in OECD countries, use various means to improve the financial state of retirees, governments' preference to adopt the DC system reflects a policy that aims to transfer the responsibility for pension savings from the governments to the individuals (Rubinstein-Levi and Kedar-Levy, 2019). It seems that most of the individuals are unable to deal with this responsibility, and substantial changes in existing policy settings are required if the goal is to induce a significant increase in savings and reduce inequality (Creedy et al., 2015). In assessing reforms and future proposals, it is necessary to keep in mind the fundamental objectives of social protection, including how to provide an income adequate to prevent poverty in old age and to provide security once people have retired (Whiteford and Whitehouse, 2006). It seems that the solution lies in increasing government regulatory intervention by creating an ideal pension institution that will have the expertise, a scale, and will operate only in the best interests of the employees (Ambachtsheer, 2007).

Group self annuitization (GSA) schemes are designed to share uncertain future mortality experience, including systematic improvements (Qiao and Sherris, 2013). GSA has considerable appeal in countries that have adopted national DC schemes (Piggot et al., 2005).

This paper shows that disadvantaged employees are associated with a higher probability of lacking pension savings, despite the existence of compulsory pensions. Disadvantaged employees who have pension savings, pay high management fees to the pension funds, among others, due to their lack of bargaining power vis-à-vis the pension funds. The paper proposes to improve the future pension income of disadvantaged employees by an aggregation model and demonstrates its microeconomic impact using Israeli data ${ }^{3}$.

\section{The Aggregation Model}

The aggregation model offered in this paper proposes to accumulate the pension savings of disadvantaged employees in a type of hybridization between a public pension fund and private pension funds, using some of the GSA principles. The idea is to create a government pension-unionizing entity that will supervise the transfer of disadvantaged employees and their employers' pension contributions to one of the pension funds that will win a tender issued by the government entity. Since the ways

\footnotetext{
${ }^{3}$ The macroeconomic and social implications are analyzed in a separate paper.
} 
that pension funds are governed affect the financial performance of their holdings (Useem and Mitchell, 2000), the pension fund that will win the tender will be supervised regularly by the government entity (Ambachtsheer et al., 1998). Moreover, the selected pension fund will be large due to the entry of all disadvantaged employees, and a larger plan size is associated with better performance of the entire pension plan portfolio (Dyck and Pomorski, 2011). The tender will enable a significant reduction in management fees due to the bargaining power of the government pension-unionizing entity vis-à-vis the pension funds, that can offer low management fees thanks to large economies of scale for pension fund administrations and lower expense ratios for large funds that decrease as funds get larger $^{4}$ (Elton et al., 2012; Bikker, 2015; Alserda et al., 2018; Bikker and Dreu, 2009).

Employees who will participate in the aggregation will receive a comprehensive response to their requests directly from the pension fund. The choice of the particular pension scheme will be according to the employees' preferences. However, since default schemes were found to have a significant impact on the savings outcomes (Beshears et al., 2009), default schemes, possibly by age, will be set for employees who prefer such schemes and for employees who have no preference for a particular scheme. The aggregation of the pension funds will be binding and enforced by synchronizing the pension payment records with the most comprehensive dataset on employers' payments, such as income tax, social security, or another governmental authority in the specific country. In the Israeli case, almost all employers transfer social security payments, thus by synchronizing the records of the pension-unionizing entity with the records of the National Insurance Institute (NII) every month, the law of mandatory pension savings will be enforced. In finer details, the enforcement of pension contributions by employers will be carried out by connecting the governmental pension-unionizing entity to a governmental entity that possesses the most comprehensive employers' payment records every month.

The disadvantaged employees' pension fund will be obligated to report to the governmental pension-unionizing entity on the transfer of pension savings, and their amount. The entity will cross-check the data, and employers who will not comply with the required contributions will be subject to sanctions imposed by law (in Israel, the NII rules), such as fines, the foreclosures of bank accounts, or in extreme cases arrests and the like 5 . The aggregation model, which has similar characteristics to pooled annuity funds, may also reduce the implications of adverse selection (Valdez et al., 2006). Although the establishment and maintenance of the governmental aggregating entity require initial investment and maintenance costs, these costs are expected to be marginal compared to the expected reduction in

\footnotetext{
${ }^{4}$ There is no evidence for diminishing economies of scale for very large pension funds (Broeders et al., 2016).

${ }^{5}$ The aggregation solution requires legal adjustments. These adjustments vary from country to country and are not discussed in this paper.
} 
support payments to retirees ${ }^{6}$.

\section{The Relevance of the Israeli Case}

Israel has a unique composition of population but shares many similarities with other OECD countries. Israel is a member of the OECD with an economy that grew at an annual rate of 4\%, with GDP per capita equaling 37,200 USD in 2016. Moreover, in 2016 household spending in Israel was $54.6 \%$ of GDP, similar to Germany and France, and to the EURO area where it was $54.5 \%$ of GDP $^{7}$. However, in Israel, the ratio of the population whose income fell below the poverty line in 2016 was high at 0.177 compared to Germany, where it was 0.101 (2015) and France with $0.083 .{ }^{8}$ Income inequality is also high in Israel, with a Gini coefficient of 0.35 in 2016. Israel has a heterogeneous society, with large sections of the population considered poor. Specifically, the ultra-Orthodox Jewish and traditional Arab sectors are poor due to low participation in the workforce and large families. As of 2017, about $49 \%$ of all Arab families are considered poor, and about $43 \%$ of all ultra-Orthodox Jewish families are considered poor?.

Israel has a well-developed financial system and uses many innovative financial instruments (Bodie and Merton, 1992). Like most other OECD countries, Israel implements the DC pension savings method. On January 1, 2008, the Israeli government instituted a mandatory pension law. There are different types of mandatory pensions. Like Austria, Belgium, France, Germany, Italy, Norway, Sweden, and the United Kingdom, the one implemented in Israel is income-related. The minimum rate of contributions for pension savings in Israel is $18.5 \%$ of the gross salary, of which the employee pays $6 \%$, and the employer pays $12.5 \%$.

In contrast to Israeli law, many employers do not contribute their part to the employee's savings account, a phenomenon that exists in other countries as well. Moreover, many Israeli employees avoid saving for retirement (Brender, 2011). As of 2015, approximately $40 \%$ of Israeli employees do not save for retirement at all, primarily due to poor enforcement of the law. Therefore, the mandatory pension low in Israel does not succeed to significantly improve the state of all retirees (Gavious et al., 2009).

The maximum management fees in Israel are extremely high, $0.5 \%$ of the accrued reserve, and $6 \%$ of the contributions. For comparison, maximum management fees in Israel are more than twice the management fees in the United States, where small pension funds collect $0.4 \%$ management fees from the accrued reserve and up to $0.64 \%$ of the contributions. Large pension funds in the United States collect $0.15 \%$

\footnotetext{
${ }^{6}$ These financial implications are analyzed in a separate paper.

${ }^{7}$ Source: OECD (2018), Household spending (indicator). doi: 10.1787/b5f46047-en.

${ }^{8}$ Source: OECD (2019), Poverty rate (indicator). doi: 10.1787/0fe1315d-en.

${ }^{9}$ Source: NII report on the dimensions of poverty and social gaps in Israel, 2017.
} 
of the accrued reserve and $0.42 \%$ of the contributions.

Like other OECD countries' governments, the Israeli government uses the tax system to encourage pension savings. However, many Israeli employees find it difficult to comprehend tax incentives, and hence do not take advantage of them, as do employees in other OECD countries (Jenkins, 2005). Overall, Israeli employees behave much like employees in other OECD countries and avoid managing their pension savings and adjusting it to their needs (Achdut and Spivak, 2010). The outcome is low pension coverage among employees, which leads to high poverty rates among retirees. The income of fifty percent of Israeli retirees would have been below the poverty line had it not been for the NII payments. That figure reduces to 30 percent once NII payments are accounted for ${ }^{10}$. It should be noted that, like other OECD countries, the medical expenses paid by the elderly in Israel are high (Baird, 2016).

\section{Disadvantaged Sectors of the Population}

Immigrant employees can generally be considered disadvantaged employees since immigrants usually work in the most exploitative, lowest paying, difficult, and dangerous jobs (Rivchin, 2003). In the United States and Canada, immigrants make, on average, over $\$ 200$ less per month than their native peers. Factors that contribute to the immigrant wage gap differ by country. In the U.S., immigrants are concentrated in low-wage jobs. In Canada, the wage gap is the result of underemployment, marginal returns on education, and discriminatory wage practices (Smith Fernandez,2015).

In Israel, Arabs and ultra-Orthodox Jews can be generally considered disadvantaged employees. The Arab population is characterized by low income and low education. An Arab man earns, on average, $54.5 \%$ of the salary that a Jewish man earns, and $13 \%$ of Arab men have an academic education, compared to $31 \%$ of the total men population in Israel. The Arab population is also characterized by employment in industries with high turnover and specialization in jobs that require physical fitness and, therefore, retirement at a young age. $26 \%$ of Arabs work in construction, $18 \%$ in trade, $16 \%$ in industry, and 3\% in agriculture. Due to the early retirement age of the Arab population, their share in the population of retirees is $23.15 \%$, while their share in the general population is approximately 20\%. Also, Arabs constitute approximately $31 \%$ of the recipients of government support payments, and approximately $37 \%$ of the population of Arab retirees receive support payments. ${ }^{11}$

The ultra-Orthodox Jewish population is characterized by low income and low education. Ultra-Orthodox Jews are employed in low-income occupations compared to the general population, and only $7.2 \%$ of the men have academic degrees,

\footnotetext{
${ }^{10}$ Source: NII reports, 2015.

${ }^{11}$ Source: Household Expenditure Survey of the ICBS, 2013.
} 
compared to $31 \%$ of the general male population. $35 \%$ of ultra-Orthodox employees work in part-time jobs. Approximately $42 \%$ of the total Jewish retiree population who receive support payments are ultra-Orthodox retirees. ${ }^{12}$

In conclusion, Arabs and ultra-Orthodox Jews can be generally considered disadvantaged employees (low socio-economic status, low status at work.), with low pension rates. These sectors of the population suffer from higher poverty rates at retirement age compared to the general population. The aggregation model is designed to improve their situation.

\section{Methodology and Research Questions}

This study is based on surveys that the Israeli Central Bureau of Statistics (ICBS) conducted and includes the ICBS's income and expenditure surveys for the years 2012-2013 and the social surveys for the years 2012-2014. The statistical analysis was carried out based on multiple variables logistic regressions, where the dependent variables are the presence or absence of pension savings.

\subsection{Data and Sampling Procedures}

The sampling process conducted by the annual ICBS surveys includes samples from the overall permanent population in Israel. The size of the surveys is about 14,000 households each year for the income and expenditure surveys, and about 7,500 respondents each year for the social surveys. The surveys use the file of residents' registry, updated for January of each year, after deduction of those who did not belong to the survey population, such as those whose age is in the category 0-19 in the social surveys or those whose age is in the category $0-15$ in the income and expenditure surveys. The method of sampling is probability sampling, which incorporates cluster sampling and layer sampling, so the results of the surveys can be attributed to the overall surveyed population (A more detailed description of the sampling method can be found in Appendix 1 and Appendix 2).

\subsection{The Research Questions}

1. Can disadvantaged employees be associated with a higher probability of lacking pension savings?

2. What effects will the implementation of the aggregation model have on disadvantaged employees?

The data analysis includes logistic regressions and calculations of the substitution ratio $^{13}$. Also, a modular pension simulator, which enables the modification and

\footnotetext{
${ }^{12}$ Source: Social Survey of the ICBS, 2014.

${ }^{13}$ The substitution ratio is the ratio between the individual's income after retirement and his/her income prior to retirement.
} 
adjustment of each of the variables that affect pension savings, was used. The prediction of the monthly income from a pension was performed by simulations that include various sensitivity analyzes. To isolate the effect of the measured variable in each simulation, a prototype of a saver with the following characteristics was set as an example:

1. Gender: male.

2. Age: 25, the average age of entry into the labor force in Israel, according to the ICBS, 2012-2014.

3. Marital status: married, the default of pension funds in Israel.

4. Insurance track: general, default.

5. Investment track: default.

6. Status: employee.

7. Retirement age: 67, the retirement age for men in Israel.

8. Gross yield: $4 \%$, the long-term yield as is customary in Israel.

9. Maximum management fees: $6 \%$ of contributions and $0.5 \%$ of the accrued reserve.

10. Contributions: as is customary in Israel, $6 \%$ employee payments, $12.5 \%$ employer payments.

11. Salary in NIS ${ }^{14}: 7,500$, the median wage of disadvantaged employees.

The implementation of the aggregation model is expected to affect disadvantaged employees at two levels, first, by creating pension savings for employees who currently lack pension savings, second by reducing the management fees paid by the employees to the pension funds. To examine the effect of creating pension savings among disadvantaged employees, the components of the gross monthly income of retirees who receive pensions and retirees who do not receive pensions are presented in the cross-section of income levels. Also, the substitution ratio of retirees who receive pensions and retirees who do not receive pensions is compared, and the effect of the age at which the pension savings begin on the monthly pension and the insurance coverages is demonstrated. The effect of reduction in management fees paid by disadvantaged employees is demonstrated by presenting the management fees paid by employees who work for large entities and by presenting the effect of different management fees on the monthly pension ${ }^{15}$.

\section{Results}

\subsection{Characteristics of Employees who Lack Pension Savings}

For the purpose of finding the demographic variables that affect the

141 NIS equals approximately $\$ 0.27$.

${ }^{15}$ The average management fees as presented on the Ministry of Finance website, 2015. 
existence/absence ${ }^{16}$ of pension savings among employees, logistic regressions were carried out. The logistic regression analysis was carried out on the ICBS's social survey data for each of the years 2012, 2013, and 2014, by implementing the Forward LR method. The dependent variable, the existence of pension savings, receives the value of 1 when the respondent owns pension savings and 0 when the respondent does not own pension savings. The independent demographic variables include age, gender, marital status, religion, number of persons in the household, net income from work, years of education, the scope of employment, and the employment sector. The reason for implementing the regressions over several years is to examine changes in the predictive variables during these years if any.

The regression model for the 2012 data was found to be significant $\left(\chi_{(16)}^{2}=869.57\right.$, $p<.001)$ and explained $37 \%$ of the variance in the variable existence of pension savings (Pseudo $R^{2}=.371$ ). The variables that entered the model as predictors with a distinctly unique and significant contribution to predicting the probability that an individual has pension savings are presented in Table 1.

Table 1. Summary of logistic regression analysis for variables predicting the existence of pension savings, 2012

\begin{tabular}{|c|c|c|c|}
\hline Predictor & $\boldsymbol{B}$ & $S E$ & Wald $(\mathrm{df}=1)$ \\
\hline Gender & -.63 & .13 & $25.48 * * *$ \\
\hline Years of education & -.14 & .05 & $6.36^{*}$ \\
\hline Number of persons in a household & -.08 & .03 & $5.21 *$ \\
\hline Scope of employment & -.45 & .15 & $9.42 * *$ \\
\hline Net income from work & -.46 & .03 & $202.75 * * *$ \\
\hline \multicolumn{4}{|l|}{ Marital status } \\
\hline Widower & 1.12 & .39 & $8.37 * *$ \\
\hline Single & .63 & .12 & $28.39 * * *$ \\
\hline \multicolumn{4}{|l|}{ Religion } \\
\hline Moslem & 1.09 & .16 & $45.01 * * *$ \\
\hline Druze & .99 & .34 & $8.34 * *$ \\
\hline \multicolumn{4}{|l|}{ Employment sector $^{17}$} \\
\hline Industry & -.35 & .18 & $4.00 *$ \\
\hline Construction & 1.06 & .22 & $23.15 * * *$ \\
\hline $\begin{array}{l}\text { Accommodation and } \\
\text { food services }\end{array}$ & .72 & .21 & $12.36 * * *$ \\
\hline Public administration & -1.9 & .61 & $9.72 * *$ \\
\hline Education & -.73 & .19 & $14.77 * * *$ \\
\hline $\begin{array}{l}\text { Health, welfare and } \\
\text { social services }\end{array}$ & -.75 & .2 & $14.56 * * *$ \\
\hline Services for & 2.29 & .46 & $24.27 * * *$ \\
\hline
\end{tabular}

\footnotetext{
${ }^{16}$ The absence of pension savings means that the employee has no pension savings at all, the existence of pension savings means that the employee has pension savings, at any level. ${ }^{17}$ As of 2013, the Central Bureau of Statistics has slightly changed some of the employment sectors, which may cause marginal differences in the findings between 2012, 2013 and 2014. These changes do not undermine the conclusions deriving from the findings.
} 
64

households by

individuals ${ }^{18}$

Note: ${ }^{*} p<.05 ; * * p<.01 ; * * * p<.001$, Number of Observations $=7,160$.

Source: Own elaboration.

The regression model for the 2013 data was found to be significant $\left(\chi_{(13)}^{2}=776.46\right.$, $p<.001)$ and explained $35 \%$ of the variance in the variable existence of pension savings (Pseudo $R^{2}=.351$ ). The variables that entered the model as predictors with a distinctly unique and significant contribution to predicting the probability that an individual has pension savings are presented in Table 2.

Table 2. Summary of logistic regression analysis for variables predicting the existence of pension savings, 2013

\begin{tabular}{|c|c|c|c|}
\hline Predictor & $B$ & $S E$ & Wald $(\mathrm{df}=1)$ \\
\hline Gender & -.80 & .13 & $37.69 * * *$ \\
\hline Years of education & -.26 & .05 & $24.75 * * *$ \\
\hline Age & .06 & .02 & $6.76^{* *}$ \\
\hline Number of persons in a household & .08 & .04 & $5.18 *$ \\
\hline Scope of employment & -.49 & .15 & $10.98 * *$ \\
\hline Net income from work & -.49 & .04 & $192.24 * * *$ \\
\hline \multicolumn{4}{|l|}{ Marital status } \\
\hline Married & -.43 & .12 & $13.34 * * *$ \\
\hline Religion & .63 & .12 & $28.39 * * *$ \\
\hline Jew & -.67 & .13 & $27.31 * * *$ \\
\hline Employment sector & .99 & .34 & $8.34 * *$ \\
\hline Construction & 1.08 & .22 & $24.32 * * *$ \\
\hline $\begin{array}{l}\text { Transport, storage } \\
\text { and communications }\end{array}$ & .62 & .21 & $8.67 * *$ \\
\hline Business services & -1.5 & 6 & $6.13 *$ \\
\hline Community, social and personal services & -.65 & .38 & $3.85^{*}$ \\
\hline $\begin{array}{l}\text { Extra - territorial } \\
\text { organizations and entities }\end{array}$ & -.62 & .21 & $8.78 * *$ \\
\hline Services for households by individuals & 1.44 & .4 & $12.95 * * *$ \\
\hline Security services & 3.17 & 1.43 & $4.91 *$ \\
\hline
\end{tabular}

Note: $* p<.05 ; * * p<.01 ; * * * p<.001$, Number of Observations $=7,438$.

Source: Own elaboration.

The regression model for the 2014 data was found to be significant $\left(\chi_{(12)}^{2}=677.19\right.$, $p<.001)$ and explained $33 \%$ of the variance in the variable existence of pension savings (Pseudo $R^{2}=.330$ ). The variables that entered the model as predictors with a distinctly unique and significant contribution to predicting the probability that an individual has pension savings are presented in Table 3. Tables 1, 2, and 3 presented show several findings that repeated over the years. In all three years, women are more likely to have pension savings than men, and the higher the income, the higher the probability of having pension savings. Also, in the employment sector

${ }^{18}$ Households that produce a variety of goods and services for their own use. 
construction and services for households by individuals, employees are more likely to lack pension savings.

Table 3. Summary of logistic regression analysis for variables predicting the existence of pension savings, 2014

\begin{tabular}{|c|c|c|c|}
\hline Predictor & $\boldsymbol{B}$ & SE & Wald $(\mathrm{df}=1)$ \\
\hline Gender & -.72 & .13 & $29.93 * * *$ \\
\hline Net income from work & -.50 & .03 & $274.33 * * *$ \\
\hline \multicolumn{4}{|l|}{ Marital status } \\
\hline Married & -.32 & .12 & $6.59 * *$ \\
\hline Widower & .94 & .42 & $5.11 *$ \\
\hline \multicolumn{4}{|l|}{ Religion } \\
\hline Moslem & 1.34 & .14 & $93.62 * * *$ \\
\hline \multicolumn{4}{|l|}{ Employment sector } \\
\hline Construction & 1.00 & .21 & $22.13 * * *$ \\
\hline Wholesale and retail trade and repairs & .48 & .16 & $8.80 * *$ \\
\hline Community, social and personal services & -1.06 & .54 & $3.82^{\wedge}$ \\
\hline $\begin{array}{l}\text { Extra - territorial organizations and } \\
\text { entities }\end{array}$ & -.6 & .22 & $7.39 * *$ \\
\hline Transport, storage and communications & .47 & .24 & $3.85 *$ \\
\hline Other services & .92 & .32 & $8.14 * *$ \\
\hline Services for households by individuals & 2.48 & .48 & $26.77 * * *$ \\
\hline
\end{tabular}

Note: $\wedge^{\wedge}<.1 ; * p<.05 ; * * p<.01 ; * * * p<.001$, Number of Observations $=7,106$.

Source: Own elaboration.

Several findings repeated only in two of the three years. In 2012 and 2013, full-time employees are more likely to have pension savings than part-time employees, and employees with more years of education are more likely to have pension savings. In 2012 and 2014, widowers are more likely to lack pension savings. In 2013 and 2014, in the employment sectors community, social and personal services, and extraterritorial organizations and entities, employees are more likely to have pension savings, while in the transport, storage, and communications employment sectors, employees are more likely to lack pension savings.

Also, during these years, married individuals are more likely to have pension savings. In 2012 the finding for singles was reversed. In 2012 and 2014, Muslims are more likely to lack pension savings. In 2012, a similar finding was obtained regarding the Druze. In 2013, Jews were more likely to have pension savings. A single finding is in the opposite direction. In 2012, the greater the number of persons in the household, the higher the probability of having pension savings, whereas in 2013, the greater the number of persons in the household, the higher the probability of lacking pension savings.

Some variables have a distinctly unique and significant contribution to predicting the existence of pension savings only in one year. In 2012, employees who work in the industry, public administration, education and health services, welfare, and social 
services, are more likely to have pension savings. In contrast, employees who work in accommodation and food services have a higher probability of lacking pension savings. In 2013, the older the employee, the higher the probability that he/she will lack pension savings. Also, in the security services employment sector, there is a higher probability for employees to lack pension savings, whereas, in the business services employment sector, there is a higher probability for employees to have pension savings. In 2014, in the employment sectors wholesale, retail trade and repairs, and other services, there is a higher probability for employees to lack pension savings.

In conclusion, the findings indicate that employees characterized by low-wages, low education, work in part-time jobs, with no employment stability in industries with a high turnover of employees, and without a unionizing entity for employees, are associated with a higher probability of lacking pension savings. Since such employees usually lack bargaining power and influence in their place of work, they cannot demand their employers to contribute to their pension savings. The aggregation of pension funds is intended to respond to this situation.

\subsection{The Effects of the Aggregation on Disadvantaged Employees}

\subsubsection{The effect of creating pension savings on disadvantaged employees}

6.2.1.1. The gross monthly income of retirees who receive pensions and retirees who do not receive pensions ${ }^{19}$

As can be seen from the comparison between Table 4 and Table 5, the total gross monthly income is significantly higher among retirees who receive pensions, compared to retirees who do not receive pensions. The effect of income from pension on the total gross income among pension recipients is significant. In the lowest income decile, the income from pension constitutes about one-fifth of the total income. In the average wage, it constitutes almost $40 \%$, and in the median wage, it constitutes one-third of the total gross income. The average income of pension recipients is higher than the average income of those who do not receive a pension at 6,469 NIS (18,124-11,655). 6,690 NIS of the average income of pension recipients is derived from their monthly pension. The income from pension is approximately the gap between the income of pension recipients and the income of retirees who do not receive a pension.

Table 4. The gross monthly income of retirees who lack pensions, in NIS

\begin{tabular}{lllll}
\hline & Lowest decile & Average & Median & $\begin{array}{c}\text { Standard } \\
\text { deviation }\end{array}$ \\
\hline Total gross income & 3,592 & 11,655 & 7,773 & 13,052 \\
Gross income from wages & 1,217 & 9,354 & 5,691 & 11,855 \\
\hline
\end{tabular}

Source: Own elaboration.

\footnotetext{
${ }^{19}$ Source: Expenditure survey of the ICBS, 2013.
} 
Table 5. The gross monthly income of retirees who receive pensions, in NIS

\begin{tabular}{lllll}
\hline & Lowest decile & Average & Median & $\begin{array}{c}\text { Standard } \\
\text { deviation }\end{array}$ \\
\hline Total gross income & 7,266 & 18,124 & 15,449 & 11,560 \\
Gross income from wages & 1,445 & 8,047 & 5,114 & 8,547 \\
Income from pensions & 1,479 & 6,690 & 5,011 & 6,455 \\
\hline
\end{tabular}

Source: Own elaboration.

6.2.1.2. The substitution ratio of retirees who receive pensions and retirees who do not receive pensions ${ }^{20}$

The substitution ratio examines the ratio between income after retirement and income before retirement. Therefore, this ratio represents the individual's ability to maintain his/her standard of living before retirement upon retiring. Adequate retirement wealth is usually defined as enough savings to provide retirees with a substitution ratio of about $70 \%$ to $80 \%$ (Booth, 2004; Weller, 2002).

The average income of retirees who do not receive pensions in NIS is 11,336 $(\mathrm{SD}=13,503, \mathrm{~N}=1,204)$. The average income of employees who do not save for retirement in NIS is 19,422 ( $\mathrm{SD}=20,679, \mathrm{~N}=2,593)$. Thus, the substitution ratio of the population who lacks pension savings is $58.37 \%$.

The average income of retirees who receive pensions in NIS is 19,436 ( $\mathrm{SD}=13,931$, $\mathrm{N}=1,151)$. The average income of employees who save for retirement in NIS is 25,278 ( $\mathrm{SD}=20,282, \mathrm{~N}=3,928$ ). Thus, the substitution ratio of the population with pension savings is $76.89 \%$.

As can be seen from the data, the substitution ratio of employees with pension savings is $32 \%$ higher than the substitution ratio of those who lack pension savings and much closer to adequate retirement wealth. Employees with pension savings are significantly more capable of maintaining a standard of living that is more similar to their standard of living before retirement, after retiring, compared to employees who lack pension savings. The rate of retirees in Israel who receive pensions as of 2013 is $48.9 \%$. The rate of employees who save for pension this year is $60.2 \%$. This means that the rate of retirees who receive a pension is expected to grow, yet the rate of employees who are not saving for a pension is still very high at about $40 \%$.

\subsubsection{Age, expected pension, and insurance coverage}

Many young employees are disadvantaged employees. Therefore, the effect of the age at which the employee begins to save for retirement on the monthly pension and the insurance coverage is presented. Below is a comparison between different ages at which the employee begins to save for retirement and its effect on the monthly pension and insurance coverage. The comparison is based on simulations of the

${ }^{20}$ Source: Expenditure survey of the ICBS, 2013. 
employee whose profile is presented, and whose monthly salary is 7,500 NIS.

Figure 1. Age, expected pension, and insurance coverage

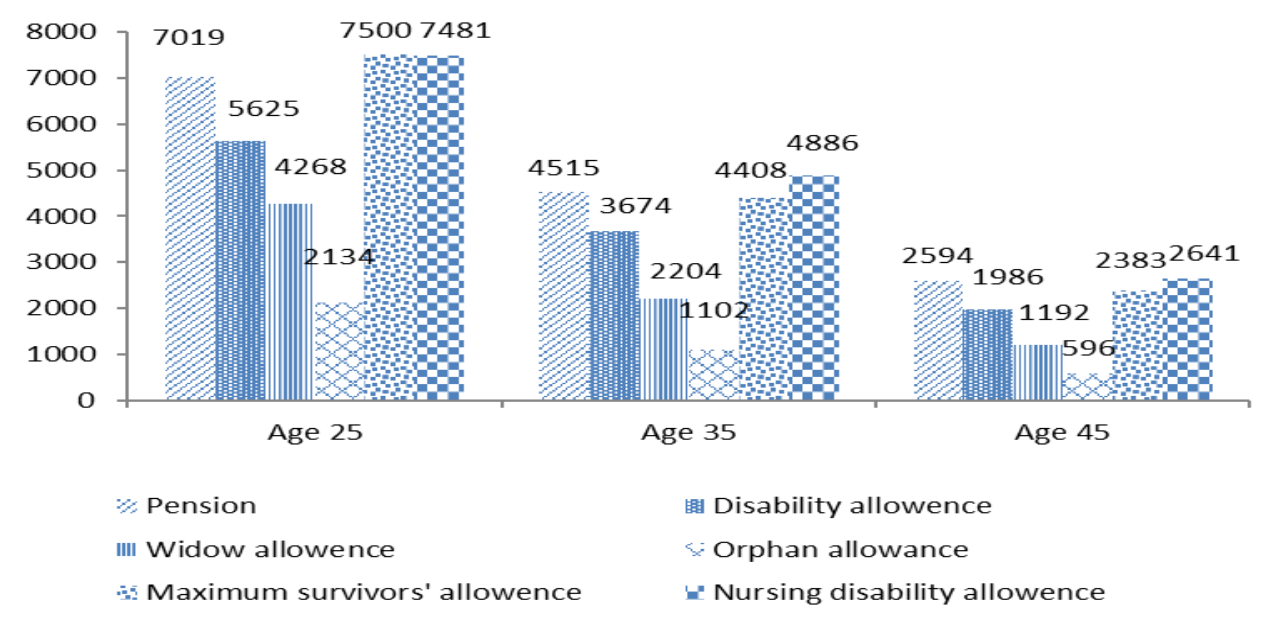

Source: Own creation.

As presented in Figure 1, there is a strong negative correlation between the age at which an employee begins to save, the expected monthly pension, and the insurance coverage. The older the employee when he/she begins to save, the lower his/her expected monthly pension and the various insurance coverages. While an employee who began to save at the age of 25 will receive a pension that constitutes $94 \%$ of his/her income, the pension of an employee who began to save at the age of 35 will constitute only $60 \%$ of his/her income and the pension of an employee who began to save at the age of 45 will constitute only $40 \%$ of his/her income.

\subsubsection{The effect of management fees}

Management fees are paid to the pension funds from the pension savings. Therefore, management fees reduce the future pension. Since large organizations have high bargaining power, their employees pay lower management fees than un-unionized employees. This difference creates a very significant gap in the expected pension ${ }^{21}$. For example, an employee whose monthly salary is 7,500 NIS and who pays maximum management fees will receive a pension of 7,019 NIS. If the same employee pays average management fees, his/her pension will rise to 7,536 NIS.

Since the management fees paid to the pension funds are divided into two, management fees from the accrual reserve and management fees from the deposits, it is difficult to compare the management fees paid by various employers. To enable comparability, Table 6 presents the expected old-age pension as a derivative of the management fees. Also, Table 7 shows the management fees from the accrual

${ }^{21}$ Management fees do not affect insurance coverage. 
reserve as average management fees from the deposits. These management fees represent the total average cost of management fees.

Table 6. Management fees paid by employees in large organizations and the expected pension

\begin{tabular}{|c|c|c|c|}
\hline Employer & $\begin{array}{l}\text { Management } \\
\text { fees from the } \\
\text { accrual }\end{array}$ & $\begin{array}{l}\text { Management fees } \\
\text { from deposits }\end{array}$ & $\begin{array}{l}\text { Expected old-age } \\
\text { pension in NIS }\end{array}$ \\
\hline $\begin{array}{l}\text { Israel Defense Forces } \\
(\text { IDF })^{22}\end{array}$ & $0.0018 \%$ & $0.0000 \%$ & 8,559 \\
\hline The state $^{23}$ & $0.0450 \%$ & $0.4500 \%$ & 8,420 \\
\hline El-Al & $0.1900 \%$ & $1.8100 \%$ & 7,982 \\
\hline $\begin{array}{l}\text { Israel Aerospace } \\
\text { Industries (IAI) }\end{array}$ & $0.1000 \%$ & $6.0000 \%$ & 7,804 \\
\hline
\end{tabular}

Source: Own creation.

Table 7. Management fees paid by large organizations

\begin{tabular}{|c|c|c|c|c|}
\hline \multirow[b]{2}{*}{ Employer } & \multirow[b]{2}{*}{$\begin{array}{l}\text { Management } \\
\text { fees from the } \\
\text { accrual }\end{array}$} & \multicolumn{3}{|l|}{ Management } \\
\hline & & $\begin{array}{l}\text { fees from } \\
\text { accrual } \\
\text { expressed as } \\
\text { from deposits }\end{array}$ & $\begin{array}{l}\text { Management } \\
\text { fees from } \\
\text { deposits }\end{array}$ & $\begin{array}{l}\text { Total average } \\
\text { management } \\
\text { fees }\end{array}$ \\
\hline $\begin{array}{l}\text { Israel } \\
\text { Defense } \\
\text { Forces } \\
\text { (IDF) }\end{array}$ & $0.00 \%$ & $0.04 \%$ & $0.00 \%$ & $0.04 \%$ \\
\hline The state & $0.05 \%$ & $1.09 \%$ & $0.45 \%$ & $1.54 \%$ \\
\hline $\begin{array}{l}\text { El Al } \\
\text { Israel }\end{array}$ & $0.19 \%$ & $4.62 \%$ & $1.81 \%$ & $6.43 \%$ \\
\hline $\begin{array}{l}\text { Aerospace } \\
\text { Industries } \\
\text { (IAI) }\end{array}$ & $0.10 \%$ & $2.43 \%$ & $6.00 \%$ & $8.43 \%$ \\
\hline
\end{tabular}

Source: Own creation.

As presented in Table 7, while savers who pay maximum management fees pay average management fees from deposits of more than $18 \%{ }^{24}$, unionized savers pay average management fees on deposits in the range of $0.04 \%$ to $8.43 \%$. The range of management fees paid by unionized savers is very broad, and the management fees paid by soldiers and state employees are significantly lower than other unionized employees. The difference in management fees leads to a significant gap in the future pension. A soldier who earns 7,500 NIS a month will receive a pension of

${ }^{22}$ The IDF management fee agreement was signed in 2011 for a period of 20 years, with an option for an additional 20 years.

${ }^{23}$ The management fees agreement for state employees was signed in 2013 for a period of 5 years.

${ }^{24}$ Through a linear transformation (Yosef and Spivak, 2006). 
8,559 NIS due to the reduced management fees he/she pays. In contrast, ununionized employee, who pays maximum management fees, will receive a pension of 7,019 NIS, a difference of almost $22 \%$. The gap in pension between an employee who pays maximum management fees and a state employee is 1,410 NIS, between him/her and an employee of El-Al 963 NIS, between him/her and an IAI employee 785 NIS, and between him/her and an employee who pays average management fees 449 NIS. Table 8 summarizes the effect of various variables on the monthly pension.

Table 8. The effect of various variables on the monthly pension

\begin{tabular}{ll}
\hline variable & $\begin{array}{l}\text { Monthly pension } \\
\text { in NIS }\end{array}$ \\
\hline The age at which savings started & \\
\hline $\mathbf{4 5}$ & 2,594 \\
$\mathbf{3 5}$ & 4,515 \\
$\mathbf{2 5}$ & 7,019 \\
Management fees & \\
\hline Maximum & 7,019 \\
Average & 7,468 \\
Of state employees & 8,420 \\
Of soldiers & 8,559 \\
Savings track & \\
General and high disability & 7.019 \\
Disability and survivors & 7,001 \\
High survivor & 7,072 \\
High savings & 7,258 \\
\hline
\end{tabular}

Source: Own creation.

As can be seen from Table 8, the effect of the various variables is different for different retirees. For example, a saver who begins to save at the age of 25 in a "high savings" track and pays management fees equal to those paid by soldiers, will receive a pension of $8,800 \mathrm{NIS}^{25}$. On the other hand, a saver who starts saving at the age of 45 in the "general" or the "high disability" track and pays maximum management fees will receive a pension of 2,600 NIS, as shown in Table 8 .

\section{Discussion and Summary}

Studies conducted in most western countries point at the DC savings method, which is implemented in most OECD countries, as a contributor to exacerbation in retirees' income inequality, poverty, and dependence on government support.

This paper shows that the DC saving method is generally detrimental to

\footnotetext{
${ }^{25}$ This combination does not appear in Table 8; it is based on a separate simulation.
} 
disadvantaged employees who are characterized by low-wages and low education, are un-unionized, work in part-time jobs, with no employment stability, and in industries with a high turnover of employees. Disadvantaged employees were found to be associated with a higher probability of lacking pension savings, despite the existence of compulsory pensions. When disadvantaged employees have pension savings, there is a high probability that they pay high management fees. The result is low pension savings and poverty at retirement age.

Employees from several sectors, such as immigrants, can be generally considered disadvantaged. In Israel, Arab and ultra-Orthodox Jewish employees are generally considered disadvantaged.

The aggregation model presented in this paper offers a way to improve the pension savings of disadvantaged employees. The model enables the implementation of compulsory pension law, thereby creates pension savings among all disadvantaged employees. In addition to that, the model enables to reduce the management fees paid by disadvantaged employees, and thus raise their future pension. The impact of the aggregation model is presented based on Israeli data and shows a significant improvement in the state of disadvantaged employees following the implementation of the model.

Given the similarity between Israel and other OECD countries in the context of pension savings, other countries may benefit from the research findings presented in this paper as well.

\section{References:}

Achdut, L., Spivak, A. 2010. The pension system in Israel after fifteen years of reform. The Van Leer Institute.

Alserda, G.A., Bikker, J.A., Van Der Lecq, F.S. 2018. X-efficiency and economies of scale in pension fund administration and investment. Applied Economics, 50(48), 51645188.

Ambachtsheer, K. 2007. Why we need a pension revolution. Financial Analysts Journal, 63(1), 21-25.

Ambachtsheer, K., Capelle, R., Scheibelhut, T. 1998. Improving pension fund performance. Financial Analysts Journal, 54(6), 15-21.

Baird, K. 2016. Paying 'til it hurts: high medical spending among the poor and elderly in ten developed countries. LIS Working paper, n. 659.

Banks, J., Smith, S. 2006. Retirement in the UK. Oxford Review of Economic Policy, 22(1), 40-56.

Been, J., Caminada, K., Goudswaard, K., van Vliet, O. 2017. Public/private pension mix, income inequality and poverty among the elderly in Europe: An empirical analysis using new and revised OECD data. Social Policy \& Administration, 51(7), 10791100 .

Beshears, J., Choi, J.J., Laibson, D., Madrian, B.C. 2009. The importance of default options for retirement saving outcomes: Evidence from the United States. In Social security policy in a changing environment, 167-195. University of Chicago Press. 
Bikker, J.A., Dreu, J. 2009. Operating Costs of Pension Funds: The Impact of Scale, Governance, and Plan Design. Journal of Pension Economics and Finance, 8(01), 63-89.

Bikker, J.A., Dreu, J. 2009. Operating costs of pension funds: The impact of scale, governance, and plan design. Journal of Pension Economics and Finance, 8(01), 6389.

Bleikh, H. 2016. Poverty and inequality in Israel: An international perspective. In D.

Chernichovsky, A. Weiss (Eds.), State of the nation report: society, economy and policy in Israel 2015: Vol. 4. Social welfare, 353-392. Taub Center for social policy studies in Israel, the Herbert M. Singer Annual Report Series.

Booth, L. 2004. Formulating retirement targets and the impact of time horizon on asset allocation. Financial Services Review-Greenwich, 13(1), 1-18.

Broeders, D.W., van Oord, A., Rijsbergen, D.R. 2016. Scale economies in pension fund investments: A dissection of investment costs across asset classes. Journal of International Money and Finance, 67, 147-171.

Creedy, J., Gemmell, N., Scobie, G. 2015. Pensions, savings and housing: A life-cycle framework with policy simulations. Economic Modelling, 46, 346-357.

Dyck, A., Pomorski, L. 2011. Is bigger better? size and performance in pension plan management. Rotman School of Management Working Paper n. 1690724.

Ellis, C.D., Munnell, A.H., Eschtruth, A.D. 2015. Falling short: the coming retirement crisis and what to do about it. Oxford University Press.

Elton, E.J., Gruber, M.J., Blake, C.R. 2012. Does mutual fund size matter? The relationship between size and performance. The Review of Asset Pricing Studies, 2(1), 31-55.

Gavious, I., Spivak, A., Yosef, R. 2009. Pension reform in Israel under mandatory pension law. Pensions: An International Journal, 14(1), 4-13

Ghilarducci, T., Saad-Lessler, J., Bahn, K. 2015. Are US Workers ready for retirement? Trends in plan sponsorship, participation, and preparedness. Journal of Pension Benefits, 25-39.

Harrison, T., Waite, K., White, P. 2006. Analysis by paralysis: the pension purchase decision process. The International Journal of Bank Marketing, 24, 5-24.

Heim, B.T., Lurie, I.Z. 2014. Taxes, income, and retirement savings: differences by permanent and transitory income. Contemporary Economic Policy, 32(3), 592-617.

Jenkins, V. 2005. Educating employers to make informed choice about financial education. Pensions: An International Journal, 10, 331-336.

Lusardi, A., Mitchell, O.S. 2017. How ordinary consumers make complex economic decisions: financial literacy and retirement readiness. Quarterly Journal of Finance, 7(03), 175008.

Lusardi, M., Alessie, R. 2011. Financial literacy and retirement planning in the Netherlands. Journal of Economic Psychology, 32, 593-608.

Munnell, A.H., Rutledge, M.S., Webb, A. 2014. Are retirees falling short? Reconciling the conflicting evidence. Issue in Brief 14-16. Center for retirement research at Boston College.

Oehler, A., Werner, C. 2008. Saving for retirement- A case for financial education in Germany and UK. An economic perspective. Journal of Consumer Policy, 31, 253284.

Piggott, J., Valdez, E.A., Detzel, B. 2005. The simple analytics of a pooled annuity fund. Journal of Risk and Insurance, 72(3), 497-520.

Qiao, C., Sherris, M. 2013. Managing Systematic Mortality Risk with Group Self-Pooling and Annuitization Schemes. Journal of Risk and Insurance, 80(4), 949-974. 
Rivchin, J.Y. 2003. Building power among low-wage immigrant workers: Some legal considerations for organizing structures and strategies. NYU Rev. L. \& Soc. Change, 28, 397.

Rubinstein-Levi, R., Kedar-Levy, H. 2019. The effect of attitudes regarding retirement on pension savings. Review of Economics and Finance, 15(1), 1-13.

Sewin, C. 2008. What you don't know can't help you: Pension knowledge and retirement decision- making. The Review of Economics and Statistics, 90, 253-266.

Smith, W., Fernandez, F. 2015. Education and wage gaps: A comparative study of immigrant and native employees in the United States and Canada. Program for the International Assessment of Adult Competencies.

Turner, J.A. 2000. Mandatory Defined-Contribution pension systems: Progress - or regression? International Social Security Review, 53(4), 25-36.

Useem, M., Mitchell, O.S. 2000. Holders of the purse strings: Governance and performance of public retirement systems. Social Science Quarterly, 489-506.

Valdez, E.A., Piggott, J., Wang, L. 2006. Demand and adverse selection in a pooled annuity fund. Insurance: Mathematics and Economics, 39(2), 251-266.

Weller, C.E. 2002. Retirement out of reach. Economic Policy Institute Briefing Paper 129.

Whiteford, P., Whitehouse, E. 2006. Pension challenges and pension reforms in OECD countries. Oxford review of economic policy, 22(1), 78-94.

Worthington, A.C. 2008. Knowledge and perceptions of superannuation in Australia. Journal of Consumer Policy, 31, 349-369.

\section{Appendix A: The Income and Expenditure Surveys of the Israeli Central Bureau of Statistics (ICBS)}

Income/expenditure surveys have been conducted regularly since 1965 . The findings pertain to the income of households in which the head of household worked as an employee, was self-employed or did not work, and also include income from wages of individuals (employees and cooperative members only). Since 1997, the income estimates have been based on combined income data elicited from two surveys: The Income Survey and the Household Expenditure Survey. The combined survey covers most of the population of Israel, in all types of localities excluding collective moshavim, kibbutzim, and Bedouin who live outside localities. The income data relate only to money income. Income Survey conducted in conjunction with the current Labor Force Survey, where one-fourth of the persons in the Labor Force Survey sample who meet the definition of the income survey population are asked about their income. Household Expenditure Survey - conducted each year since 1997 and designed to elicit the components of household budgets and to determine the weights of each component in the "consumption basket" that is used in computing the Consumer Price Index. Respondents in the survey are asked about both their income and their expenditure. The survey sample in both surveys is a sample of dwellings, and all households who tenanted each dwelling chosen for the sample on the enumeration date are enumerated (usually, one household per dwelling).

The samples in both surveys were extracted in a two-phase process: In the first phase, extraction of a sample of localities using the layer method, and in the second phase, extraction of dwellings in a random-systematic manner in each chosen locality. The mainframe for the extraction of the sample of dwellings is the municipal property-tax file. Samples of dwelling units complemented the main samples of the dwelling in student dormitories, immigrant absorption centers, and sheltered-housing facilities for the elderly. 
Also, the samples were updated during the survey year by adding new dwellings that were chosen from a special frame composed of newly built dwellings. The data are based on a net sample of about 14,000 households for each year- about 8,000 from the Income Survey sample and about 6,000 from the Household Expenditure Survey sample. Survey period: the data for the Income Survey were collected from four quarterly surveys. In each quarterly survey, every member aged 15+ of each selected household was asked about his/her income during the three months ending the month before of the enumerator's visit. Thus, each annual survey investigates quarterly income over fifteen months. The data for the Household Expenditure Survey were collected for about thirteen months, during which data on income were collected for each household member aged 15+, and data on expenditures were collected for the household as a whole.

The questionnaires collected in the field undergo manual checking, editing, and coding. After the data are transferred to magnetic media, a series of logical checks are conducted specifically to find and correct mistakes in the file: checks of links between different variables, checks for total amounts, and so on. Also, missing data are supplemented, and questionnaires in which data are defective, and there is no way to correct them, are disqualified. The purpose of the various checks is to correct mistakes that can be corrected and, at the same time, to eliminate from the final survey data that are deficient and cannot be corrected. All income data were standardized to the price level. An additional source of income data is the NII. However, certain constraints limit the attempt to compare data from the combined survey with sources from the NII. In the NII data, income is calculated per employee job, and in the combined survey, income is calculated per employee.

Therefore, an employee working in more than one place of work appears some times in the NII data, and the average income calculated per employee based on the NII data is lower than the income per employee in the combined survey. However, not every person registered with the NII worked three full months; this fact influences the opposite direction, due to the calculation of the average every month. Despite the differences in absolute data regarding income from various sources, it is possible to use the data on income received from the survey efficiently, both for examining the differences in income between various population groups and for estimating the changes in incomes over a period of time. The estimation method is designed to reduce both sampling errors and the biases that may occur due to the possibility that non-responding households have different characteristics than households that participated in the survey.

To obtain estimates for the survey population at large, a "weighting coefficient" was determined for each enumerated household and for all persons belonging to that household. The weighting coefficient of a household reflects the number of households and the number of persons in the survey population who are represented by this particular household. In the calculation of these weighting coefficients, the "non-response" cases were also taken into account (cases that should have been investigated but were not), as well as cases that were rejected due to missing data about the respondents' income or the extent of their work. The set of weighting coefficients was determined in a multi-phase "raking" process, in which the distribution of the weighted sample was adjusted for several external distributions, according to selected distribution variables. The adjustment for each of the distributions was made according to 1. Household characteristics; 2. Individual characteristics - separately (not combined). Among households, a different adjustment was made for those residing in Arab localities, for new immigrants who settled in Israel up to four years ago, and for the rest of 
the population, according to the following distributions: 1. Homogeneous groups of households, as determined by statistical methods, by the level of consumption expenditure; 2 . Groups of types of households determined based on the size and age composition of the household (for example, elderly persons living alone, young couples, households with children, etc.); 3. Groups of households defined based on the time they were investigated. These groups are meant to balance the weighted sample over the survey year and to prevent biases that might result from the fact that the survey sample was not evenly distributed over the months of the year, due to fieldwork constraints. The household-characteristic distributions to which the survey data were adjusted were derived from the Labor Force Survey estimates that are based on a large sample (4 times greater than the Income Survey sample). For data pertaining to individuals, the weighting coefficients for the various groups of households were determined in a way that would also assure full correspondence between the survey estimates and the distribution of the survey population according to sex, age, and geographic cross-sections, in accordance with the current demographic data of the ICBS.

\section{Appendix B: The Social Surveys of the ICBS}

The Social Survey has been conducted annually since 2002 on a sample of persons aged 20 and older. The main purpose of the Social Survey is to provide up-to-date information on the welfare of Israelis and their living conditions. The social survey questionnaire has two main parts: a core questionnaire containing about 200 items covering the main areas of life such as health, housing, employment, economic situation, and a variable module devoted to a different topic each year to investigate it in greater detail than is possible in the core questionnaire. The questionnaires are administered by ICBS interviewers using laptops to conduct computer-assisted personal interviews (CAPI).

The interviews are conducted in Hebrew, Arabic, and Russian. An interview lasts about an hour. The table generator allows for deriving both estimates of persons and households. The survey population comprises the permanent non-institutional population of Israel aged 20 and older, as well as residents of non-custodial institutions (such as student dormitories, immigrant absorption centers, and independent living projects for the elderly). New immigrants are included in the survey population if they have been present in Israel for at least six months. Groups not included in survey population: residents of custodial institutions (eg., nursing homes, hospitals for the chronically ill, prisons), Israelis abroad for more than a year without interruption at the time of the survey, diplomats, new immigrants who arrived fewer than six months before the interview, Bedouin tribes residents, and others living outside the boundaries of localities.

The Social Survey is the first survey conducted by the ICBS using the Population Register as a sampling frame. In general, the quality of the sampling frame depends on the degree to which it covers the survey population: under-coverage can lead to biased estimates, while over-coverage leads to higher costs because of attempts to enumerate persons who are not part of the survey population. Therefore, persons not belonging to the survey population were removed from the sampling frame. The desired final sample size for each year is 7,500 persons aged 20 and older. The expected size of each design group was to be proportional to its size in the population, under the constraint of a final total sample size of 7,500 completed interviews. The initial sample includes about 9,500 persons to obtain 7,500 respondents. Data collected in the Social Survey come from a sample of the population. To provide estimates based on the survey for the total population and sub-groups, it is necessary to compute for 
each person a weight, which reflects the number of persons in the population whom he "represents". In the present form of the table generator, weights of a person divided by the number of persons in the household aged 20 and overexpresses the estimated number of households in the population whom he "represents", thus allowing the derivation of estimates of households.

The method of estimation takes into consideration both the sampling method and the difficulties in data collection. The estimation method is intended primarily to minimize bias resulting from informative non-response, from under-coverage of specific groups and variations in sample size according to characteristics (such as education or labor force participation), which were not taken into account in the sample design. The estimation procedure involved three stages:

First, each respondent received an initial weight, which was the inverse of their sampling probability, as a correction for non-response. The initial weight reflects the differential sample design and the differential response in a narrow geographical cross-section. To carry out the second stage, adjustment variables were selected. The distribution of these variables was known from administrative sources or was estimated from the Monthly Labor Force Survey, and they had the strongest correlation with the most important variables included in the Social Survey core questionnaire. Thirdly, final weights were computed by the method of "raking", in which the distribution of the weighted sample obtained from the second stage was adjusted to the distributions of five external estimates: 1. Estimates of households by population group: extended household size -38 groups. 2. Estimates of persons aged 20 and over by population group: sex and marital status -12 groups. 3 . Estimates of persons aged 20 and over by population group: labor force characteristics and education -11 groups. 4 . Estimates of persons aged 20 and over by population group: geographical groups and distinction between the ultra-Orthodox population, based on administrative sources (according to educational institutions) and the rest of the population (for persons aged 2064): for persons in Jewish and mixed localities - 27 groups. 5. Estimates of persons aged 20 and over by population group: geographical groups, sex, and age groups -234 groups. 